\title{
8. The Kammavācās.
}

\section{Hampstead, March 21, 1892.}

Deir Professor,-In the last number of the "Journal" I had occasion to notice the fact of the sudden introduction of Burmese into the Pāli text of the Kammavāeās. Since writing that article I have had the opportunity of studying a MS. in which whole sentences in Burmese follow the Päli (not, of course, in the way of Nissaya, that is common enough).

Being on paper made from the bark of the mulberry and opening both ways, this MS. has, at first sight, all the appearance of an ordinary Shan book, but in reality it consists of a Collection of Kammavācās in Pāli and of Instructions to the Shin (Sāmanera) and Pyin Shin (Upasampanno) in Burmese, together with a few final directions in Shan.

The order of the Kammavācās differing from that of the other MSS., it may be well to mention it:-

1. Upasampadā.

2. Saṁghādisesā (Suddhantaparivāsa, chāratta, abbhāna) beginning:

Aham puttarakkhito bhilkhu ...

4. Kathinadussam.

4. Ticīvarena avippavāsa.

5. Uposatha.

Mr. St. John has kindly pointed out to me that, the Burmese which I transliterated sunkrimvrat (p. 73) is thōn gyane $y \bar{u} t$, i e. tikkhattum vattabbo.-Yours truly,

Herbert Baynes. 